\title{
Deepening Democracy: A Farm Workers' Movement in the Western Cape
}

\section{FIONA WHITE}

(Centre for the Study of Democracy, University of Johannesburg)

\begin{abstract}
This article explores the internal dynamics and external impact of a South African farm workers' movement, Sikhula Sonke. It looks at the extent to which this women-led 'social movement trade union' has succeeded in improving the livelihoods of Western Cape farm workers. Drawing from the organisation's own aims, it investigates whether the movement has created a democratic organisational structure, addressed social and economic inequality on Western Cape farms and effectively challenged unfair labour practices. The article argues that the movement, although facing historical conditions of disempowerment, has set up the foundations of an empowering representational structure. It has begun to address the social challenges of paternalism, patriarchy and racism between workers and, through an effective use of strategies that target both employers and government, successfully challenged numerous cases of unfair labour practice. Furthermore, beyond meeting its immediate aims, there are broader lessons that can be learnt from Sikhula Sonke. The movement deepens participatory democracy in the Western Cape through its ability to empower citizens and its use of political institutions. More significantly, Sikhula Sonke opens up spaces for greater participation in the democratic system by its use of 'radical' and 'moderate flanks' and by exploiting the multidimensional nature of the state.
\end{abstract}

\section{Introduction}

South Africa is a country whose inhabitants struggled for decades to achieve the right to political equality. Resistance to apartheid and the transition to democracy were difficult processes, yet they offered potentially rich rewards, the most significant of which was democratic citizenship. However, the post-apartheid era has now entered its second decade and this reward has yet to have a positive impact on the many South Africans who face ever-increasing socio-economic inequality. After almost a decade of democracy it was estimated that nearly 48.5 per cent of the population fell below the poverty line and that inequality in income distribution was actually rising. ${ }^{1}$ It is against this backdrop of widespread poverty and inequality that post-apartheid social movements have arisen. Socio-economic issues, such as access to medicine, land and service delivery spur their formation and their activities. Although the impact these new movements have on the post-apartheid political system is still unfolding, it is instructive to assess the extent to which they achieve their organisational aims and meet their members' needs. Furthermore, it is important to understand what lessons can be learnt from their successes and 'failures'. This article analyses the role of one social movement, a farm workers' trade union, and its ability to further the aims of farm

1 United Nations Development Programme, South Africa Human Development Report 2003 (Oxford, Oxford University Press, 2003), p. 5. 
workers in the Western Cape. It then looks at what can be learnt from the movement in relation to South Africa's political system more generally. The article demonstrates that there are many unplanned consequences of the movement's work that deepen participatory democracy in the Western Cape. This points to new ways in which social movements increase government accountability and responsiveness and so strengthen South African democracy.

\section{Sikhula Sonke: Origins and Objectives}

Farm life, in other words, lacks any fully independent 'civil society': few forms of organisation not mediated by the authority of the farmer exist ... farm workers' struggle is a struggle for such a 'private space', for civil society itself. ${ }^{2}$

It is into this context, an arena devoid of independent civil society, that a new farm workers' union emerged in the Western Cape. Sikhula Sonke (meaning 'We Grow Together' in isiXhosa) defines itself as a 'women-led social movement trade union', there to deal with all the livelihood challenges faced by farm women. ${ }^{3}$ In many respects it developed organically out of the needs of farm workers, but it was also invented, in the face of necessity, by the NGO Women on Farms (WFP). WFP wanted to support an 'organisation of the workers not for the workers' ${ }^{4}$ Thus, in 2002 a new, potentially self-sustaining, representative association for women farm workers was formed. Eight years later the movement has nearly 5,000 members, drawn from over 200 different farms in ten geographic locations in the Western Cape. ${ }^{5}$

WFP had not initially conceived of Sikhula Sonke as a trade union. ${ }^{6}$ However the movement soon evolved into a union because, as Sikhula Sonke President Sarah Classen explains, one of the most pressing problems facing wine and fruit farm workers was limited access to effective union representation. ${ }^{7}$ Existing unions did operate in the fruit and wine industries; however, Sikhula Sonke's founders felt they were unreliable and ineffectual: 'As a farm worker I had lived through five unions already. They came from the cities and were never around at wage negotiations'. ${ }^{8}$ Sikhula Sonke's objectives, however, stretch beyond those of a traditional trade union. The organisation has a broad social mandate. It is 'more than a union because we look at more than labour problems. We look at all issues that affect women and their children'.

A central tenet of Sikhula Sonke's organisational structure is its dual nature as a 'social movement trade union'. Sikhula Sonke understands that neither a social movement nor a trade union alone is as effective in meeting members' interests as a hybrid structure. A dual organisation is able to focus both on social issues (such as racial discrimination and

2 A. du Toit, 'The Micro-Politics of Paternalism: the Discourses of Management and Resistance on South African Fruit and Wine Farms', Journal of Southern African Studies (JSAS), 19, 2 (1993), p. 335.

3 Interviews with Wendy Pekeur, General Secretary, Sikhula Sonke, February-May 2007, Stellenbosch, and Sikhula Sonke, 'Profile', unpublished document, 2006.

4 Interviews with Fatima Shabodine, Director, Women on Farms, 26 April and 3 May 2007, Stellenbosch and Cape Town.

5 Namely: Bottleray, Strandweg, R44 Branch, Paarl, Wellington, Franschhoek, Grabouw, Villiersdorp, Ceres and Rawsonville. Telephonic interview with Sandra Hendricks, Administrator, Sikhula Sonke, 22 February 2010.

6 Interviews with Fatima Shabodine. Sikhula Sonke formally split from WFP in 2009.

7 Interview with Sara Claasen, President, Sikhula Sonke, 19 April 2007, Stellenbosch. There are approximately 203,000 employees on Western Cape farms, supporting nearly 1.5 million dependants. C. Van Louw, 'Strategic Plan for Farmworkers' (unpublished document, Department of Agriculture, Western Cape, 2005). Sikhula Sonke mainly works with fruit and wine farms.

8 Interview with Estelle Coetzee, Organiser, Sikhula Sonke, 8 May 2007, Stellenbosch.

9 Interview with Evelien Ockers, Organiser, Sikhula Sonke, 19 April 2007, Stellenbosch. 
government service delivery) alongside workplace concerns (such as wage negotiations). Indeed, members join Sikhula Sonke because it can help with a wide range of concerns, such as 'the conditions we live in on the farm'; 'alcoholism problems'; 'evictions' or 'getting an ID'. 10

Sikhula Sonke understands that social and labour concerns facing farm workers are interlinked. To take one example: a traditional trade union may not deal with alcohol misuse from a social perspective as Sikhula Sonke does; at the same time, however, widespread alcoholism on Western Cape farms is a contributing factor as to why workers struggle to defend their working conditions or wages. ${ }^{11}$ Broadening its scope beyond traditional trade union activities allows the movement to have a multipronged approach to tackling the livelihood concerns of its members and, in so doing, makes it more effective in meeting members' needs. Conversely, its structure as a trade union is likewise an asset to its role as a social movement. Functioning as a trade union allows Sikhula Sonke to build a membership base, with subscription paying members, that perhaps may be more committed and active than non-fee paying social movement members. The trade union status also confers on Sikhula Sonke an authority as a legitimate organisation with a paid membership base behind it. It may thus carry more weight when engaging employers and the state.

In line with its 'social movement trade union' identity Sikhula Sonke aims to,

craft an organisational model that will not only challenge the unfair labour practices applied to women farm workers, but also ... address the social and economic development needs of women who live and work on farms. ${ }^{12}$

In order to achieve these aims, the movement focuses on a range of activities. For example, Sikhula Sonke aims to build strong leadership structures, based on democratic principles and to be representative of the diversity of workers in the agricultural sector. In order to improve the position of women farm workers, the organisation also focuses on running collective campaigns, conducting effective negotiations and building good relationships with government structures and employers. ${ }^{13}$ Drawing from the movement's own stated goals, the following sections look at how and whether Sikhula Sonke are able to achieve three key aims: building a democratic movement; addressing the social and economic development needs of farm workers; and challenging unfair labour practices.

\section{Building a Democratic Movement}

If Sikhula Sonke is to 'craft an organisational model' that will achieve its aims, its officials need to represent members' needs effectively and honestly. This section will question whether the movement's leadership structures support democratic principles, and set the foundations for an effective representational structure.

At its core sit Sikhula Sonke's full-time staff of ten who oversee the day-to-day running of the organisation, but it is a 'workers [sic] led organisation'. ${ }^{14}$ For this reason, officially, the

10 Interviews with Sikhula Sonke members from farms in the Cape Winelands, March- May 2007, Western Cape.

11 Alcohol misuse is a problem on farms in the Western Cape, due primarily to the legacy of the 'dop' system, an arrangement whereby workers were given wine as part of their wage package. Despite its official prohibition the system still persists on some farms. The abuse of alcohol has led to high levels of work accidents as well as violence amongst workers. This affects Sikhula Sonke's union work because, 'Every day there is a worker drunk at work and every second day a worker is dismissed for drinking'. Interview with Evelien Ockers.

12 Sikhula Sonke, 'Profile' (unpublished document).

13 War on Want, 'Women Farm Workers in South Africa', available at http://www.waronwant.org/overseas-work/ food-justice/women-farm-workers-in-south-africa, retrieved on 12 January 2010.

14 Interview with Estelle Coetzee. 
most important decision-making body in the movement is its Annual Congress: 'Everything has its roots in Congress'. ${ }^{15}$ The Congress is an annual general meeting composed of representatives sent from each branch through whom 'members explain what they want and what Sikhula Sonke must do for the following year'. ${ }^{16}$ It is in this forum that strategic decisions are made, policy decided and campaigns planned. ${ }^{17}$ Every three years the Congress elects the National Executive Committee (NEC) and the General Secretary. By all accounts, the Congress is not only the highlight of the Sikhula Sonke year but also a successful democratic structure that allows elected members to articulate their needs to those who make decisions. ${ }^{18}$

As with traditional trade unions Sikhula Sonke attempts to implement a comprehensive representative structure. It does so through three membership levels. The highest representative structure is the NEC which, in conjunction with the full-time staff, builds on the work done at Congress, setting a more detailed agenda of what will be addressed in the organisation. The NEC wields accountability over staff, especially the General Secretary: 'Sikhula Sonke does have a culture of being held accountable when things are not happening. The general secretary will come under fire from the NEC'. ${ }^{19}$ This accountability arises from the understanding that it is members who mandate the NEC to ensure all work is properly carried out. ${ }^{20}$ The NEC does not, however, function flawlessly. Where there are faults it is primarily due to a lack of experience and therefore weakened capacity on the part of NEC members. ${ }^{21}$

Branch Executive Committees (BEC) form the second representative layer. ${ }^{22}$ Monthly BEC meetings are allocated the responsibility of monitoring the implementation of the Congress's plan of action and are also to be used to develop strategies and as a forum for holding the leadership (NEC and staff) accountable. ${ }^{23}$ In practice, BECs are not well established and operate irregularly. Not all compulsory annual general branch meetings take place according to schedule, and even in cases where they do occur monthly they are yet to function effectively in terms of the tasks allocated to them. ${ }^{24}$

The third representative layer of Sikhula Sonke is that of Farm Committees. Each farm is supposed to have a Farm Committee with between five and seven members who function in a similar manner to shop stewards. Committee members are elected by Sikhula Sonke general members on the farm. An important tenet of Farm Committees is that of self-organisation and self-activity; they are responsible for issues such as domestic violence, assault and disciplinary hearings. ${ }^{25}$ Committee members must also engage with farmers about working conditions. In practice, however, as with the BECs, Farm Committees are not fully established. As one staff member noted, 'Some farms are not working that well... Some members are very active and some are not very active'. ${ }^{26}$

15 Interview with Colette Solomon, Deputy Director, Woman on Farms, 8 May 2007, Stellenbosch.

16 Interview with Marthina Smith, Deputy President, Sikhula Sonke, 11 April 2007, Stellenbosch.

17 Interview with Edgar Blaauw, Caseworker, Sikhula Sonke, 24 April 2007, Stellenbosch; interviews with Wendy Pekure.

18 Based on interviews with WFP staff, Sikhula Sonke staff and the Sikhula Sonke NEC.

19 Interviews with Fatima Shabodine.

20 Interview with Estelle Coetzee.

21 Interviews with Fatima Shabodine.

22 Where there are more than 100 members in a district those members may form a branch, with each branch having a ten-member committee. Sikhula Sonke, 'Grondwet van Sikhula Sonke' (unpublished paper, Stellenbosch, 2004). By 2007 Sikhula Sonke had eight established branches, although there is potential for 34.

23 Woman on Farms. 'Woman on Farms Project Annual Report 2006' (unpublished report, Stellenbosch, 2006), p. 60 .

24 Observation of discussions in a Field Team Meeting and Organisers meeting, April 2007, Stellenbosch.

25 Bottleray Branch Annual General Meeting, 31 March 2006, Stellenbosch and De Klapmuts Farm Committee Meeting, 4 May 2006, Stellenbosch.

26 Interview with Hannes Visagie, Organiser, Sikhula Sonke, 2 April 2007, Stellenbosch. 
A key reason underlying the weakness of BECs and Farm Committees is a lack of organisational experience on the part of ordinary members. Although trade unions have existed on farms in the past, they have not been widespread and workers have little experience of mobilising and forming representative organisations. More challenging however, is the legacy of paternalism and entrenched experiences of subordination. Paternalistic farm relations have meant that farm workers are not accustomed to articulating their needs in a professional and sustained manner. Contrary to apartheid experiences in many urban areas, where organisations such as street committees existed, there are minimal recorded histories of social mobilisation on farms in the rural Western Cape. Sikhula Sonke is trying to counteract this lack of experience and deep-rooted feelings of inadequacy by providing training for BEC members and Farm Committee members. It may take some time before representative structures at the lower levels of the organisation function effectively. Sikhula Sonke has, however, attempted to craft a democratic and representative organisational model. As a relatively new organisation, with an inexperienced leadership and membership base, work still needs to be done to ensure these democratic principles result in an effective democratic culture.

\section{Addressing Social Inequality on Western Cape Farms}

A second key aim of Sikhula Sonke's is to address the social and economic development needs of its members. In practice, this means tackling entrenched notions of social inequality on farms; fostering social equality is seen as the first step towards challenging economic inequality (the section on unfair labour practices deals in more detail with how Sikhula Sonke addresses the economic needs of its members). Sikhula Sonke focuses on three main areas of social inequality: employer-employee relations; gender relations and relations between workers from different racial groups.

When looking at employee-employer relationships it is clear that paternalism persists on Western Cape farms. Du Toit explains how paternalism works: the farmer is viewed, and indeed views himself, as 'pa staan vir die werkers', that is 'occupying the place of the father'; when workers are employed on a farm they do not simply enter into a formal business relationship but become 'deel van een familie' and 'deel van die plaas' - 'a part of the family' and 'a part of the farm'. At the heart of paternalism is the notion that worker and farmer ultimately share a common interest in the survival of the farm community. ${ }^{27}$ Paternalism is not necessarily always a harmful relationship; farmers can provide a fair wage package and, for example, medical care, education, transport and crèches. However, in South Africa's deeply embedded racial and social practice, paternalism on many farms also embodied the notion that some people have rights, as citizens, and others, like children, are the subjects of a master: 'Some farmers see workers as minors and as minors they cannot be a political subject. Race and mastery are seen as equivalent'. ${ }^{28}$ Workers have had little sense of power in the working environment because "paternalism gives the farmer a unique authority as 'speaking subject' ... workers' voices do not count: formally they have no 'authority', no 'licence"". ${ }^{29}$ It is this dynamic that Sikhula Sonke are trying to

27 Du Toit, 'The Micro-Politics of Paternalism: the Discourses of Management and Resistance on South African Fruit and Wine Farms', pp. 320-1.

28 Interview with Andries du Toit, Plaas Researcher, 26 April 2007, Cape Town.

29 Du Toit, 'The Micro-Politics of Paternalism: the Discourses of Management and Resistance on South African Fruit and Wine Farms', p. 323. Employer-employee relations do differ from farm to farm and there are examples of good practice on some farms, although these are in the minority. 
change by getting workers to understand that they are citizens of a state with both human and labour rights.

Through training and empowerment, Sikhula Sonke has been very successful in helping workers embrace their rights, but this has come with complications. Many farm workers are now caught between a paternalist discourse and a detached 'rights-based' approach to their labour. They want both a formal unionised relationship with an employer and to feel a part of the farm family. A side-effect of the formalisation of working relationships, moreover, has been that some workers now face worse living conditions as they have no access to social benefits and services previously provided by farmers. Where there is a legal requirement, such as access to water, Sikhula Sonke will try to ensure this is enforced. But where benefits are part of a paternalistic relationship they may be lost in a formal 'rights-based' framework. Indeed, the very opportunity to gain employment may decrease for coloured workers. Andre Bloem, a labour consultant representing farm owners, maintains that the 'entire set up' of farms will change with 'black not coloured people being employed' as black workers only want wages without the complications of employment packages that include housing, for example. Certainly for Bloem, 'the social and economic conditions of farm workers have changed for the worse [sic] because of unions'. ${ }^{30}$

Despite these complexities, Sikhula Sonke's work in challenging paternalism has been significant. By empowering farm workers it has confronted the long entrenched notion that 'the power of judgement is a privilege reserved for the farmer'. ${ }^{31}$ As a movement it provides strength to workers to contest not only existing social inequalities, including racial inequality, but - potentially - economic inequality too. If, in the context of private land ownership, power relations can never be equal between farm owners and workers, Sikhula Sonke nevertheless are building a sense of value and worth amongst workers that could take them some way towards a healthier balance of power between a much-marginalised community and the 'baas'. ${ }^{32}$

A second form of inequality addressed by Sikhula Sonke is that of gender. Although agricultural workers as a whole are perhaps 'worse off than those in every other sector of the economy, ${ }^{33}$ it is women and non-permanent workers within this sector that are the most marginalised. Common problems facing women farm workers include: lower wages compared to men; no housing for single women; no independent employment contracts for married women, whose security of employment and housing, therefore, is dependent on spouses; and no paid maternity leave. ${ }^{34}$ As one movement member explained, during her entire working life on the farm she has been paid less than her husband. ${ }^{35}$ The deep-rooted patriarchy and gendered abuse experienced by women farm workers is perhaps best illustrated in a chart drawn up by women describing their working day, compared with that of the men around them: ${ }^{36}$

It is these patterns of subordination and inequality between men and women that Sikhula Sonke seeks to change. In farm meetings, for example, organisers explain the importance of treating women as valued and equal members of a family. They also address more sensitive issues such as the abuse of young girls. ${ }^{37}$ Within its own leadership structures Sikhula Sonke clearly supports the role of women. As an organiser clarifies, 'we did let men join,

30 Interview with André Bloem, Boland Labour Consultant, 4 May 2007, Paarl.

31 Du Toit, 'The Micro-Politics of Paternalism: the Discourses of Management and Resistance on South African Fruit and Wine Farms', p. 323.

32 A widely used Afrikaans term for 'boss'.

33 C. Prince, 'Conditions on Farms: A Draft Paper' (Western Cape, Unit for Social Research, Western Cape Department of Social Services and Poverty Alleviation, 2004), p. 3.

34 Ibid., p. 3.

35 Interview with Marthina Smith.

36 A group exercise compiled by women farm workers in a WFP workshop. See A. Schuster (ed.), Remember Me? Stories from Women Who Work on Farms (Stellenbosch, Women on Farms Project, 2002), pp. 34-5.

37 Observed at Bottleray Branch Annual General Meeting. 


\begin{tabular}{|c|c|c|c|}
\hline \multicolumn{2}{|c|}{ Women } & \multicolumn{2}{|l|}{ Man } \\
\hline $5 \mathrm{am}$ & I wake up and go to the toilet & $5 \mathrm{am}$ & Sleeping \\
\hline 6am & I prepare to go to work & $6 \mathrm{am}$ & Sleeping \\
\hline $7 \mathrm{am}$ & Out of the train in the station to work & $7 \mathrm{am}$ & I wake up and dress \\
\hline $8 \mathrm{am}$ & Start work - plant grapes, remove seeds & $8 \mathrm{am}$ & $\begin{array}{l}\text { I eat all the food that the women } \\
\text { have cooked }\end{array}$ \\
\hline 9am & I am working & 9am & I am at the shebeen \\
\hline 10am & I am working & $10 \mathrm{am}$ & I am drinking \\
\hline $11 \mathrm{am}$ & I am working & $11 \mathrm{am}$ & I am drinking \\
\hline $12 \mathrm{am}$ & Lunch & $12 \mathrm{am}$ & I am drinking more \\
\hline $1 \mathrm{pm}$ & I start to work again & $1 \mathrm{pm}$ & I am lying down \\
\hline $2 \mathrm{pm}$ & I am working & $2 \mathrm{pm}$ & I am lying down \\
\hline $3 \mathrm{pm}$ & I am working & $3 \mathrm{pm}$ & I wake up and go to the shebeen \\
\hline $4 \mathrm{pm}$ & I am working & $4 \mathrm{pm}$ & I drink more alcohol \\
\hline $5 \mathrm{pm}$ & I am working & $5 \mathrm{pm}$ & I am at the shebeen \\
\hline $6 \mathrm{pm}$ & I am working & $6 \mathrm{pm}$ & I am at the shebeen \\
\hline $7 \mathrm{pm}$ & $\begin{array}{l}\text { I arrive at home and start to cook food } \\
\text { for supper and wash myself }\end{array}$ & $7 \mathrm{pm}$ & I am at the shebeen \\
\hline $8 \mathrm{pm}$ & I dish supper & $8 \mathrm{pm}$ & $\begin{array}{l}\text { I come back to see if the wife } \\
\text { has cooked after work }\end{array}$ \\
\hline $9 \mathrm{pm}$ & I wash dishes after supper & $9 \mathrm{pm}$ & $\begin{array}{l}\text { I discover that she has not } \\
\text { cooked and punish her }\end{array}$ \\
\hline $10 \mathrm{pm}$ & I sleep & $10 \mathrm{pm}$ & $\begin{array}{l}\text { I force her to cook and eat all } \\
\text { that food }\end{array}$ \\
\hline $11 \mathrm{pm}$ & I sleep & $11 \mathrm{pm}$ & $\begin{array}{l}\text { I lie down in the bed with my } \\
\text { muddy shoes }\end{array}$ \\
\hline & & $12 \mathrm{pm}$ & I am sleeping \\
\hline
\end{tabular}

but... women are the leaders' ${ }^{38}$ The NEC is composed almost entirely of women and this is something they hope to replicate at lower levels. ${ }^{39}$ Furthermore, Sikhula Sonke negotiates with farmers to pay women wages equal to those of men. Although changing entrenched understandings of gendered roles is challenging, the organisation has taken the first step in recognising the need to reduce gender inequality within the farm worker community.

Third, Sikhula Sonke tries to equalise relations amongst different racial groups working on farms. This is in keeping with its aim to represent the diversity of workers within the agricultural sector. The organisation represents three constituencies: permanent workers; seasonal, casual or contract workers; and 'non-workers ${ }^{40}$ who live in the communities in which the organisation operates. Permanent workers, generally living on the farm, have historically formed a part of the Cape Coloured community. Defining the Cape Coloured community is a complex task, partly because this is a racial grouping created by an apartheid state and partly because, as a community, they have no clear single historical lineage. ${ }^{41}$ Indeed it is this lack of clear lineage that some commentators believe foster many of the

38 Interview with Evelien Ockers.

39 Interviews with Wendy Pekeur.

40 Interviews with Wendy Pekure.

41 G. Lewis, Between the Wire and the Wall: a History of South African 'Coloured' Politics (Cape Town, David Philip, 1987), p. 4. 
current social problems experienced by the community. ${ }^{42}$ Seasonal, casual or contract workers, who do not live on farms, are described by Ewert and du Toit as, 'a rural lumpen proletariat' ${ }^{43}$ Seasonal or casual workers are primarily Xhosa-speaking Africans migrating from the former homelands of the Eastern Cape in search of jobs and a better life. ${ }^{44}$ According to the Director of WFP, the influx of Africans into the farm areas is a relatively recent phenomenon and most are migrant seasonal woman workers. ${ }^{45}$ Not all migrate however; some reside permanently in towns in the winelands, or commute from Khayalitsha, on the Eastern edge of Cape Town.

Currently, Sikhula Sonke membership is dominated by permanent workers. This is something that staff hope to change, explaining that seasonal workers are the most vulnerable with minimal job security and little protection from the law. ${ }^{46}$ The relatively low number of seasonal worker members is a reflection of the difficulty in accessing and recruiting workers who do not live on farms and are often migrants. Seasonal workers are also frequently employed by labour brokers, rather than farmers themselves, making them harder to unionise. A further challenge in recruiting seasonal workers is that they may not self-identify as farm workers. According to du Toit they identify as poor rural citizens first. ${ }^{47}$

Alongside trying to recruit seasonal workers, Sikhula Sonke also tries to build unity between its different members by showing farm workers what their common interests are regardless of race or background. It is important to note, however, that "workers are not a homogenous body. Power exists among workers themselves and important struggles are fought within their ranks. The coming of a union can therefore easily have undemocratic implications'. ${ }^{48}$ It is a testament to Sikhula Sonke's focus on equality that this is not a noticeable feature of the union. Organisers recognise the vulnerability of all members, whether coloured or African, and in so doing try to ensure equality in the way they are treated and the way they relate to each other. Although reducing social inequality is a daunting task for any social movement, Sikhula Sonke has made inroads into reducing social inequality between farmers and workers, between women and men and between different races.

\section{Challenging Unfair Labour Practices}

A third key aim of Sikhula Sonke's is to challenge unfair labour practices. Sikhula Sonke employs two broad strategies for achieving this aim: first, directly engaging with and, where necessary, contesting employer's actions and, second, engaging with and influencing government policy making and policy implementation with regards to farm workers' rights.

\section{Engaging Employers}

Sikhula Sonke will try to influence employers and represent members' interests in a variety of ways. At first, staff try to resolve labour disputes with the employer/farmer directly, through discussion or negotiation. 'We try to build relationships. It disadvantages members if you are

42 Interviews with Fatima Shabodine. W. James, D. Caliguire and K. Cullinan (eds), Now That We are Free: Coloured Communities in a Democratic South Africa (Cape Town, IDASA, 1996).

43 J. Ewert and A. du Toit, 'A Deepening Divide in the Countryside: Restructuring and Rural Livelihoods in the South African Wine Industry', Journal of Southern African Studies, 31, 2 (June 2005), p. 317.

44 J. Ewert and J. Hamman, 'Labour Organisation in Western Cape Agriculture: An Ethnic Corporatism?', in H. Bernstein (ed.), The Agrarian Question in South Africa (London, Frank Cass, 1996), p. 162.

45 Interviews with Fatima Shabodine.

46 Interview with Estelle Coetzee; Interview with Evelien Ockers; Interview with Sara Claasen.

47 Interview with Andries du Toit.

48 Du Toit, 'The Micro-Politics of Paternalism', p. 336. 
constantly aggressive. On some farms, farmers and workers have a very good relationship and this empowers workers to do things for themselves' (General Secretary of Sikhula Sonke). ${ }^{49}$ On the farm Die Eike, for example, although workers were paid below the minimum wage, by negotiating with the farmer, Sikhula Sonke ensured that the farmer met the legal requirements. ${ }^{50}$ It is interesting to note that in its dealings with employers Sikhula Sonke have yet to advocate striking: 'We don't say to workers that they must strike... Workers have a right to strike, but striking can cause people to lose jobs and houses. There is always a way to bring parties together to try to solve the problems'. ${ }^{51}$

If negotiation does not work, Sikhula Sonke will resort to other strategies, including using the Commission for Conciliation, Mediation and Arbitration (CCMA) and the Labour Court. According to a Commissioner, "the CCMA is user driven. The mere fact of using it is important and Sikhula Sonke uses the CMMA a lot'. ${ }^{52}$ Not only does Sikhula Sonke use the CCMA 'a lot', but it does so quite effectively by challenging employers and refusing to allow intimidation of workers. ${ }^{53}$ It has had the majority of cases decided in its favour. Where it has won CCMA cases it has in many instances secured a livelihood for an individual. ${ }^{54}$ Using the CCMA and the Labour Court is also important for addressing the paternalistic farmer/farm worker relationship. The CCMA can be an empowering environment for farm workers as their views are listened to on equal terms to their employer. ${ }^{55}$ Judgements in favour of workers can also set a precedent, ensuring that farmers feel compelled to maintain legal working conditions. Most importantly, the CCMA and Labour Court allow historically marginalised workers to engage with the state as citizens, rather than as subjects of their employer, an experience they previously seldom enjoyed.

Sikhula Sonke has also been successful in influencing employers indirectly: the organisation ran a workers' rights campaign aimed at getting the British retailer, Tesco, to improve labour conditions on farms from which it buys fruit. Sikhula Sonke members bought three shares in Tesco and attended their 2006 AGM in London. During question time at the AGM a Sikhula Sonke member presented information on working conditions and asked what Tesco planned to do to ensure it lived up to its creed of 'ethical sourcing'. The delegation was received positively, and Tesco's chairperson personally met with them after the AGM. Aside from receiving significant media coverage in the UK, ${ }^{56}$ the encounter had measurable benefits for workers. ${ }^{57}$ Although an isolated episode, this campaign is a good example of influencing employers by utilising members' moral authority on a global stage. The campaign demonstrated that Sikhula Sonke understand and can utilise broader relations of power in order to achieve its local aims.

Although Sikhula Sonke is active in holding farmers to account it must be recognised that its track record in improving wages is limited. According to Bloem, many farmers believe the

49 Interviews with Wendy Pekeur.

50 Interview with André Bloem.

51 Interview with Evelien Ockers.

52 Interview with John Brown, CCMA Commissioner and Woman on Farms Board Member, 13 April 2007, Cape Town.

53 Interview with John Brown; Observations of Sikhula Sonke CCMA Hearings, March-May 2007, Cape Town and Paarl; Interviews with Wendy Pekeur.

54 Where Sikhula Sonke feels CCMA judgements are unjust it will refer cases to the Labour Court.

55 Based on observations at Sikhula Sonke CCMA Hearings.

56 'Fruit Picker Wins Tesco's Support', Guardian (8 July 2006); 'African Worker Tells Tesco to Honour the Fruits of her Labour', The Independent (8 July 2006); 'The South African Fruit Picker Taking on Tesco', Daily Mirror (7 July 2006).

57 Tesco have since approached the Wine and Agricultural Ethical Trade Association (WIETA) and asked them to develop an auditing methodology for working conditions in the fruit chain. Major Tesco supplying fruit companies in South Africa have agreed to be audited through WIETA. Woman on Farms, 'Woman on Farms Project Annual Report 2006' and interviews with Wendy Pekeur. 
movement has "not had any impact on wage negotiations at all' ${ }^{58}$ There is only minimal evidence that the union has influenced long-term economic reform on the majority of farms where it operates. However, the movement has been fairly successful in challenging localised cases of unfair labour practice. Certainly from an employer's perspective it could be argued that farmers are 'more respectful of Sikhula Sonke as a union than they are of other independent unions'. 59

\section{Engaging the State}

Sikhula Sonke challenges unfair labour practices by attempting to influence government actors and, in turn, government policy making and implementation, even though this is not a core focus of the organisation's work. Sikhula Sonke has a fairly broad range of governmental campaigns centred on workers' rights, living conditions and social issues. This section examines how the organisation has used a range of strategies, including utilising government commissions, directly targeting government departments and officials, forming alliances, joining public forums and using mass action. It concludes by discussing how the movement is perceived by government actors: is Sikhula Sonke viewed as a legitimate and effective representative of farm workers' interests?

Sikhula Sonke actively uses government commissions, such as the constitutionallydelineated Human Rights Commission (HRC) and the Employment Conditions Commission (ECC) to influence government policy. The movement has, for example, made submissions to the HRC regarding human rights violations and lodged a case with the HRC regarding the alleged rape of a farm worker by her employer. ${ }^{60}$ Sikhula Sonke frequently engages with the ECC through submissions regarding sectoral determination, by means of which government legislates and controls the terms and conditions of employment for workers in a particular sector, including setting minimum wages and housing standards for workers living on an employers' premises. ${ }^{61}$

Sikhula Sonke members went to ECC hearings at the Department of Labour: 'we had banners and t-shirts and some members spoke at the gathering ... They told their stories'. ${ }^{62}$ By ensuring its members were represented at the hearings, Sikhula Sonke played an important role in getting the ECC to scrap the two-tier system prescribing different minimum wages for rural and urban areas. Although it was unable to get the minimum wage raised to the level that workers had testified in public hearings was a living wage, the Department of Labour acknowledged that by taking members to the sectoral determination hearings Sikhula Sonke had 'forced the department to communicate properly with workers' ${ }^{63}$ Indeed, the movement's influence on the findings of the Commission was significant, with the result that 'before the ECC made their findings to the Minister they first called us ... it was clear that the ECC was flooded with concerns, but they still came to us to justify how they had reached the sectoral determination amount'. ${ }^{64}$

58 Interview with André Bloem.

59 Interview with John C. Anthony, ANC Councillor, Klapmuts, 25 April 2007, Klapmuts.

60 Interviews with Wendy Pekeur. Interview with Edgar Blaauw. Sikhula Sonke, 'Narrative Report to War on Want' (unpublished paper, Stellenbosch, March 2007).

61 Paralegal Advice, 'Labour Law', Paralegal Manual, (2002), available at http://www.paralegaladvice.org.za, retrieved on 12 June 2007.

62 Interview with Sara Claasen.

63 Interview with Zulaigha Smith, Regional Manager, Department of Labour, Somerset West, 3 May 2007, Somerset West. The minimum wage in urban areas was set at R1,041, and in peri-urban/rural areas at R989 per month. Workers had testified to a living wage of R1,200 per month (Department of Labour, 2007; Women on Farms, 'Women on Farms Project Annual Report 2006').

64 Interviews with Fatima Shabodine. 
Along with its use of state institutions, Sikhula Sonke also engages with individual government departments and officials. The organisation has been successful in holding government departments to account where it presents individual cases involving working conditions or wages to the Department of Labour, or cases regarding social grants to the Department of Social Welfare. Although these are limited in scope and have no bearing on government policy they can have considerable benefits for the members they directly affect. Sikhula Sonke staff also attended Department of Labour Forums. Here, Sikhula Sonke ensured that farm worker concerns were brought to the attention of department officials. ${ }^{65}$ Although Sikhula Sonke staff often feel the Department of Labour does not respond to their requests and is ineffectual, ${ }^{66}$ from the point of view of a Labour Centre Manager Sikhula Sonke is seen as 'a very visible organisation who ensure we do our work properly. They will bring destitute people to your door if you do not respond' ${ }^{67}$ Sikhula Sonke has also informally engaged with the Department of Agriculture. Although the movement feels the MEC for Agriculture has not been very supportive, ${ }^{68}$ a ministerial spokesperson felt that 'they have an open door to our Department' and 'we do sit and talk about common problems when we have the chance'. ${ }^{69}$

Sikhula Sonke's campaign against farm dweller evictions is one example of how the movement has successfully targeted government decision-makers. The primary focus of this campaign has been to respond to the growing farm workers' housing crisis, which has resulted from both the frequency with which farmers are choosing to replace permanent workers living on farms with migrant and seasonal labourers and from the inadequacy of existing land tenure security laws. ${ }^{70}$ The 1997 Extension of Security of Tenure Act (ESTA) strengthened the rights of workers occupying housing provided by a farmer. ${ }^{71}$ Workers are, in theory, less vulnerable to arbitrary evictions. The effect of ESTA, however, has been that many farmers are now reluctant to have workers living on their land. As one farmer explains: "If there is no one working in a house on our farm, but it is occupied because of ESTA, we call this a "dead house"... We have demolished seven houses because of ESTA. We want to demolish more because we cannot get people off the farm and out of houses. ${ }^{72}$ Stronger tenancy laws are thus resulting in fewer houses being available for farm workers. Equivalent off-farm housing stock is more costly and brings with it transport costs and, in some cases, a weakened sense of community.

Sikhula Sonke, however, as part of a collective effort, was able to win the first ever moratorium on farm dweller evictions. The movement helped form the Jonkershoek Crisis Committee, which generated substantial media coverage of evictions in Jonkershoek, near Stellenbosch. ${ }^{73}$ About 600 people, many of whom were Sikhula Sonke members, marched $2 \mathrm{~km}$ through Stellenbosch before handing over a memorandum to a representative of the Western Cape Premier. The protest successfully demonstrated the combined size and tenacity of farm workers and had the important effect of succeeding in getting key decision makers (including the Western Cape MEC for Agriculture and the Mayor of Stellenbosch) to agree to a moratorium on evictions in Jonkershoek. They also accepted that the land tenure policy for farm workers is inadequate and needed to be reviewed. The decision to implement a moratorium on

65 Sikhula Sonke, 'Narrative Report to War on Want'.

66 Interview with Ida Jacobs, Organiser, Sikhula Sonke, 8 May 2007, Stellenbosch.

67 Interview with Zulaigha Smith.

68 Interviews with Wendy Pekeur.

69 Interview with Alie Van Jaarsveld, Spokesperson: Western Cape Ministry of Agriculture, 30 April 2007, Cape Town.

70 Woman on Farms, 'Woman on Farms Project Annual Report 2006'.

71 Republic of South Africa (No. 62 of 1997) 'Extension of Security of Tenure Act', Government Gazette (Republic of South Africa, 1997).

72 Interview with Francois Malan, Owner, Simonsig Wine Farm, 24 April 2007, Stellenbosh.

73 See 'Farmworkers Stage Anti-eviction March', Cape Times (28 April 2006) and 'Farmworkers in Eviction March', Sunday Argus (3 April 2006) among many others. 
evictions in Jonkershoek was taken because 'Sikhula Sonke posed threats in terms of mass action; they explained that blood would flow if the evictions were not stopped. Because of these calls we felt compelled to deal with the problem'. ${ }^{74}$ Following on from this agreement, a stakeholder forum was established with key role-players. Indeed, the provincial Ministry of Agriculture felt that the process of dialogue and constructive engagement might well be the first of its kind in agricultural communities and could serve as a blueprint for other provinces. ${ }^{75}$

Sikhula Sonke also hopes to influence government policy by joining collaborative government forums. Among these, perhaps the one Sikhula Sonke is most involved with is the Black Association of the Wine and Spirit Industry (BAWSI). BAWSI brings together individuals and interested parties from historically disadvantaged communities in the wine sector. ${ }^{76}$ It both creates a platform where unions can address challenges they face and make contributions to several government forums. As a BAWSI project manager explains: 'We open doors to government structures. In addressing the challenges of the agricultural sector we need to do this collectively with social partners including government' ${ }^{77}$

In conjunction with joining government forums, Sikhula Sonke has worked effectively with other civil society organisations, embracing the idea of networking and learning from other organisations: 'We are still young so we talk to other organisations for help. We get information where we can to guide us'. ${ }^{78}$ One of its most important relationships is with the Congress of South African Trade Unions (COSATU). Although it is not an affiliate of COSATU, the latter has a 'good relationship' with Sikhula Sonke. ${ }^{79}$ This is significant because COSATU have a policy of working with only one trade union per sector and its affiliate on farms in the Western Cape is the Food and Allied Workers Union (FAWU). In making this exception, COSATU Western Cape has chosen to work fairly closely with Sikhula Sonke because 'they have done a lot of good work with a much marginalised group' ${ }^{80}$ Sikhula Sonke also has good relations with other like-minded organisations such as the Western Cape based Alliance of the Land and Agrarian Reform Movements (ALARM), Alternative Information and Development Centre (AIDC) and the International Labour Research and Information Group (ILRIG). At ILRIG, Sikhula Sonke is viewed in a positive light, as 'promising' and a 'quite resilient' social movement union. ${ }^{81}$ Lastly, Sikhula Sonke has worked effectively with WFP since its inception. This strong relationship has been central to its success in many of its government-focused campaigns.

Finally, Sikhula Sonke influences government policy making and implementation through mass action. This can take several forms, including marches, rallies and establishing resistance committees with like-minded organisations. Additionally, staff use the media to publicise mass action or critical farm worker issues. Although Sikhula Sonke supports independent cases of mass action, it will also utilise mass action in conjunction with its other strategies of negotiation and using forums and state institutions. As WFP explained, 'We are stronger because when we go to engage with policy makers we have woman farm workers outside the door' ${ }^{82}$ Sikhula Sonke's work in Jonkershoek demonstrates its effective use of mass action.

74 Interview with Alie Van Jaarsveld.

75 Ministry of Agriculture: Western Cape, 'Statement by Cobus Dowry, Minister of Agriculture Western Cape: Road Forward for Jonkershoek' (unpublished document, 2006).

76 Wines of South Africa, Black Association of the Wine and Spirit Industry (undated), available at http://www. wosa.co.za/sa/empower_bawsi.php, retrieved 13 June 2007.

77 Interview with Freddie Lindoor, Labour Project Manager, BAWSI, 25 April 2007, Stellenbosch.

78 Interview with Marthina Smith.

79 Interview with Tony Ehrenreich, COSATU Western Cape Provincial Secretary, 26 April 2007, Cape Town.

80 Interview with Tony Ehrenreich.

81 Interview with Leonard Gentle, Acting Director, ILRIG, 6 February 2007, Cape Town.

82 Interviews with Fatima Shabodine. WFP and Sikhula Sonke frequently lobbied policy makers together. 
To conclude this section it is important to ask how government and political actors view Sikhula Sonke. Do they see the organisation as a 'balanced opposition' able to improve government accountability and responsiveness? ${ }^{83}$ Interviews with Western Cape politicians and officials point to conflicting feelings about the work of the movement. On the one hand, there is the view that Sikhula Sonke does good work in a highly marginalised community; on the other, when it challenges the government too vigorously it is seen as undermining, unhelpful and 'too political'. There is support and admiration for Sikhula Sonke when it works with government structures, but wariness and scepticism when it directly confronts government actors.

For example, the provincial Department of Agriculture has indirectly funded the activities of Sikhula Sonke through WFP. ${ }^{84}$ This indicates that, at one level, there is positive support and acknowledgement of the movement. However, when Sikhula Sonke confronts the department, about evictions for example, the department feels that, 'Sikhula Sonke behave like they are still pre-1994 ... They should be beyond mass action because we are all partners now. We should rather sit and talk than fight in public'. ${ }^{85}$ A similar dual perspective exists in the District Mayor's office. They recognise that they share areas of similar interest to social movements like Sikhula Sonke but feel that the movement needs to work out where it can input into government planning rather than 'constantly blaming government' ${ }^{86}$

Bearing this ambivalence in mind, it is clear that the Department of Agriculture believe Sikhula Sonke, and WFP, have the potential to be an effective watchdog. They acknowledge that Sikhula Sonke exposes irregularities and to some extent functions as their 'eyes and ears on the ground'. ${ }^{87}$ Similarly, the District Mayor's office accepts that Sikhula Sonke's General Secretary, 'speaks her mind ... she is listened to and in this way they are effective in voicing women farm workers' issues'. However, they conclude that Sikhula Sonke does not engage with government at the level where it matters, where policy is constructed, and thus miss opportunities to influence government actors effectively. ${ }^{88}$

In contrast, the local Department of Labour and local councillors were less conflicted in their support of Sikhula Sonke. The Labour Centre manager acknowledged that Sikhula Sonke was a vocal organisation that effectively monitored the Centre's work, often calling meetings when it felt that the Department was responding to its requests inadequately. The manager furthermore felt that 'Sikhula Sonke get things done. They do not accept a closed door approach. They are very resourceful and knowledgeable and informed about what affects them,' and ultimately that, 'Sikhula Sonke do improve people's lives'. 89 A similar level of support was voiced by African National Congress (ANC) councillors. There was also recognition that 'Sikhula Sonke is doing a very good job' and is not afraid to approach both farmers and politicians. ${ }^{90}$ Indeed, staff and members 'use many platforms, including going to where a Minister is and fighting with him and questioning him'. ${ }^{91}$ Councillors interviewed considered Sikhula Sonke to be a 'progressive organisation' in a context where farm workers struggle to protect their interests and engage with the state and employers. ${ }^{92}$

83 See G. White, 'Civil Society, Democratization and Development: Clearing the Analytical Ground', in P. Burnell and P. Calvert (eds), Civil Society in Democratization (London, Frank Cass, 2004) for one theory behind the importance of a 'balanced opposition' to government power.

84 Interview with Alie Van Jaarsveld.

85 Interview with Alie Van Jaarsveld.

86 Interview with Clarence Johnson, Cape Winelands District Mayor, 8 May 2007, Stellenbosch; Interview with Gwebs Qonde, Cape Winelands Deputy Municipal Manager, 8 May 2007, Stellenbosch.

87 Interview with Alie Van Jaarsveld.

88 Interview with Clarence Johnson; Interview with Gwebs Qonde.

89 Interview with Zulaigha Smith.

90 Interview with Gordon Pheiffer.

91 Interview with John C. Anthony.

92 Interview with Gordon Pheiffer; Interview with John C. Anthony. 
The difference in perspectives of the different sectors (agriculture and labour) and different layers (provincial, district, and municipal) shows the unevenness of the state and the difference in lobbying for better policy implementation (Somerset West Department of Labour) versus policy making (Provincial Department of Agriculture). Sikhula Sonke has had greater success in the former and finds the latter more challenging. However, improving both is important if the organisation is to effectively and systemically challenge unfair labour practices and strengthen the rights of farm workers.

Sikhula Sonke may have challenges to overcome but it is, in aggregate, a successful social movement trade union. It has made significant inroads into achieving its aims by laying the foundations for a democratic movement and consistently challenging social and economic inequality and unfair labour practices. The movement is most effective in meeting its aims on an individual level; as one member explains: 'It is very good to be a member. Things have changed a lot in my life. I have started to stand on my own feet'. ${ }^{93}$ In addition, it also strengthens the influence of members on a broader scale. For example, one interviewee contemplated: 'Can Sikhula Sonke change discourses? Can they get workers political agency as citizens?' Ultimately he concluded that, 'They have a better chance of making a difference than any other organisation'. ${ }^{94}$

\section{Implicit Aims: Sikhula Sonke and the Deepening of Democracy}

The plight of farm workers shows that, for many in South Africa, formal democracy has resulted in some disappointments. Yet, in the mere act of joining a social movement that engages with employers and the state, farm workers demonstrate the hope that the political system they live in can one day provide for them. And, indeed, an analysis of Sikhula Sonke teaches us that, even if unplanned, a social movement's actions can (and here do) deepen democracy. Sikhula Sonke plays an important role in strengthening democracy through its ability to empower citizens and its use of political institutions. More significantly however, Sikhula Sonke demonstrates new ways to open up space for greater participation in the democratic system by its use of 'radical' and 'moderate' strategies and by its understanding of the multidimensional state.

\section{Empowering Citizens}

Sikhula Sonke members have little experience of citizenship or of perceiving themselves as citizens. Farm workers in general are marginalised in terms of their citizenship rights, experiencing for example, 'great difficulties in accessing social services', which heightens their vulnerability and exposes them to 'human rights violations and abuse'. ${ }^{95}$ Certainly farm workers in the Western Cape did not play a major role in the anti-apartheid struggle. ${ }^{96}$ When democracy did come to South Africa, 'farm workers were one group of people that were left behind'. ${ }^{97}$ As the WFP Director explains, 'There is a need to convince people that they have innate rights. Farm workers have faced centuries of internalised oppression'. ${ }^{98}$ In this context, it is noteworthy that Sikhula Sonke has made inroads into turning farm workers into citizens.

Through its ongoing work in educating its members about their human and workers' rights, Sikhula Sonke is effectively empowering farm workers. Indeed, for many members,

93 Interview with Marthina Smith.

94 Interview with Andries du Toit.

95 Prince, 'Conditions on Farms', p. 3.

96 Observation based on interviews with Evelien Ockers, Tony Ehrenreich, Fatima Shabodine and Freddie Lindoor.

97 Interview with Alie Van Jaarsveld.

98 Interview with Fatima Shabodine. 
joining Sikhula Sonke is seen as a way of gaining some power, whether as a woman or a worker. Many democratisation theorists argue that where citizens develop a stronger sense of their own right to claim rights or express opinions they are better able to engage in participatory processes between elections and as government watchdogs. ${ }^{99}$ More empowered citizens allow for a more 'significant voice in public policy decisions', which in turn can 'reduce poverty and enhance equity among all groups'. ${ }^{100}$ Thus, creating citizens, as Sikhula Sonke does with its members, both helps members meet their immediate needs and has the unintended consequence of strengthening participatory democracy in the Western Cape.

\section{Political Institutionalisation}

Sikhula Sonke sees much value in working directly with state structures, such as courts, commissions or parliamentary forums. This strategy has the unintended consequence of helping to build state institutions capable of both constraining, where necessary, and imparting information to executive power. Maladies in new democracies often point to weaknesses in the rule of law and in public accountability, where there are no strongly institutionalised checks and balances. ${ }^{101}$ To counter these problems, democracies need to develop governments that are subject to horizontal accountability: to a network of relatively autonomous institutions that can call into question, and eventually punish, improper ways of discharging the responsibilities of a given office. ${ }^{102}$ Horizontal accountability can be enhanced by societal actors, including the media and civil society, trying to enforce standards of good conduct on state actors. ${ }^{103}$ Thus, Sikhula Sonke fosters political institutionalisation where it strengthens the agents of horizontal accountability: political institutions.

Simply using state institutions such as the HRC and CCMA underpins them and thus leads to a concomitant strengthening of democracy. Yet Sikhula Sonke not only uses state structures, it contests them where necessary. However, it does not do so in an anomic or destructive manner. Sikhula Sonke endeavours to make democratic institutions work for it rather than trying to replace them or undermine them. In this way, the movement is positively reinforcing South African democracy.

\section{Moderate and Radical Flanks ${ }^{104}$}

Beyond creating empowered citizens and strengthening political institutions, Sikhula Sonke illustrates how social movements can make government and political actors more accountable and responsive to the needs of the poor and marginalised. In so doing, it, again, inadvertently strengthens South Africa's nascent democracy. Through an effective

99 See J. Gaventa, 'Towards Participatory Governance: Assessing the Transformative Possibilities', in S. Hickey and G. Mohan (eds), Participation: From Tyranny to Transformation (London, Zed Books, 2004), p. 37 and F. White, 'Strengthening Democracy? The Role of Social Movements as Agents of Civil Society in PostApartheid South Africa' (Ph.D. thesis, University of London, Institute of Commonwealth Studies, 2008).

100 Blair, cited in Gaventa, 'Towards Participatory Governance', p. 32.

101 A. Schedler, L. Diamond and M. Plattner (eds), The Self-Restraining State: Power and Accountability in New Democracies (Boulder CO, Lynne Rienner Publishers, 1999), Introduction.

102 G. O'Donnell, 'Horizontal Accountability in New Democracies', in Schedler, Diamond and Plattner (eds), The Self-Restraining State, p.165.

103 A. Schedler, 'Conceptualising Accountability', in Schedler, Diamond and Plattner (eds), The Self-Restraining State.

104 A radical flank is the part of a social movement which 'is more likely to use disruptive or illegal tactics and which develops a more pure (and less compromising) distillation of the movement's guiding ideas'. See Goodwin and Jasper, The Social Movements Reader: Cases and Concepts, p. 347. See also D. McAdam, J.D. McCarthy and M.N. Zald (eds), Comparative Perspectives on Social Movements: Political Opportunities, Mobilizing Structures, and Cultural Framings (Cambridge, Cambridge University Press, 1996), p. 14. 
combination of strategies, including participatory engagement with the state (its moderate flank) and strategies of direct action (its radical flank), Sikhula Sonke's members are listened and responded to, and in turn democratic accountability is deepened.

\section{The Moderate Strategy: Participatory Engagement}

One of Sikhula Sonke's key strategies is to engage the state through its participatory avenues, such as joining government forums, inputting into commissions such as the ECC, and making submissions (often with WFP) to parliamentary committees. This attempt to engage the state is significant, as participatory governance, or 'the opening up of core activities of the state to societal participation' can lead to improved 'accountability and governance'. ${ }^{105}$ However, in practice, participatory governance processes may generate few meaningful responses.

South African analysts have argued that there is little evidence that 'formal participatory structures have enabled citizens to influence policy' and that since the onset of formal democracy there 'have been few new opportunities for meaningful political participation'. ${ }^{106}$ Participatory mechanisms are also seen as biased towards those with the capacity to organise; participatory structures or forums furthermore compel civil society to engage with the government on its own terms. Governments can institutionalise participation, channelling organisation of the 'hitherto excluded' for their own ends on a national scale. ${ }^{107}$ Indeed, the recent rise in social protests around the country, which are often violent and related to service delivery, demonstrate that citizens feel there are few effective participatory avenues through which to articulate their needs and generate responsiveness. ${ }^{108}$ Thus, if social movements are to generate effective government responsiveness, which in turn can minimise socio-economic inequality, they must use a broad range of strategies alongside participatory governance.

\section{The Radical Strategy: Direct Action}

A common component in a broad range of strategies is direct action, and this Sikhula Sonke uses extensively, particularly through marches and rallies. Direct or mass action can be effective in compelling a government to recognise (although seldom respond to) a movement's needs. Certainly, a wide range of social movement scholars has shown how disrupting public order can generate success for a movement in meeting its aims. ${ }^{109}$ For Tarrow, it is disruption, or the threat of it, that increases movement effectiveness. ${ }^{110}$ However, research into social movements has shown that mass or direct action, on its own,

105 J. Ackerman, "Co-Governance for Accountability: Beyond "Exit" and "Voice", World Development, 32, 3 (2004), pp. 447-63, p. 448.

106 See S. Friedman, 'Participatory Governance and Citizen Action in Post-Apartheid South Africa' (unpublished paper, presented at International Institute of Labour Studies Workshop: Participatory Governance: A New Regulatory Framework, Geneva, 2005), p. 3 for the former, and B. von Lieres, 'Citizen Participation in South Africa: Land Struggles and HIV/AIDS Activism', in A. Cornwall and V. Coelho (eds), Spaces for Change? The Politics of Citizen Participation in New Democratic Arenas (London, Zed Books, 2007), p. 229 for the latter.

107 M. Stiefel and M. Wolfe, A Voice for the Excluded. Popular Participation in Development: Utopia or Necessity? (London, Zed Books, 1994), p. 101.

108 Government records show that in 2004/2005 there were 5,800 nation-wide protests, in 2005/6 this had nearly doubled to 10,763. J. Duncan, 'Reply to Parliamentary Question on Protest Action', Debate [online], available from debate-bounces@lists.kabissa.org, retrieved 26 November 2007.

109 McAdam et al., Comparative Perspectives on Social Movements, p. 14.

110 S. Tarrow, Power in Movement: Social Movements, Collective Action and Politics (Cambridge, Cambridge University Press, 1998). 
generates few positive policy changes. ${ }^{111}$ This challenge speaks to Young's question of whether 'activist challenges' or 'deliberative democracy' is most effective in undermining injustice. ${ }^{112}$ Young concludes that 'protesting and making demands from the outside may be an effective way to bring attention to injustices that require remedy ... but on their own they do not propel the positive institutional change that would produce greater justice.' Thus, organisations need to 'both engage in discussion with others to persuade them that there are injustices that ought to be remedied and to protest and engage in direct action'. ${ }^{113}$ Protest is important but ineffectual unless accompanied by more traditional lobbying activities. ${ }^{114}$

The effectiveness of using both direct action and participation is illustrated by the social movement concept of the radical flank effect. A radical approach is effective when its threat to authority is so great that authorities are compelled to deal with the more moderate side of the movement. ${ }^{115}$ Sikhula Sonke's positive engagements with government structures, alongside its mass action, illustrates the benefit of providing a moderate face with which the government can negotiate. Generating effective government responsiveness may be best achieved by movements that are willing to present a moderate strategy in their interactions with the government and the state. As other civil society researchers have noted, a dual power approach can be very effective in strengthening influence over policy making. ${ }^{116}$ This requires gaining power within local government through strategies of collaboration and partnership, while keeping strong community organising strategies active at the grassroots. Sikhula Sonke shows us how a social movement inadvertently strengthens democratic accountability by using dual strategies of influence.

\section{The Multidimensional State}

Discussion of the use of dual strategies points to a second important way in which Sikhula Sonke illustrates how civil society can generate more effective governmental responsiveness and in so doing strengthen democracy: embracing the multidimensional nature of the state.

Viewing the state as holistic, or in undifferentiated terms, gives the misleading impression that it pulls in a single direction. The state is not a unitary actor that strategically assesses it interests and acts accordingly; rather, its different elements pull in different directions. ${ }^{117}$ Civil society can thus interact with different spheres, institutions and individuals of the state to generate responsiveness. Sikhula Sonke demonstrates an effective understanding of the multiple dimensions of the state. It works with both national institutions such as the courts and local institutions such as Labour Centres, but it also lobbies individuals, including provincial ministers. Each activity generates different responses, some more effective than others in terms of influencing. However, Sikhula Sonke's approach highlights the state's accessibility. It is not a closed entity, resistant to all forms of policy

111 White, 'Strengthening Democracy?'.

112 I.M. Young, 'Activist Challenges to Deliberative Democracy', Political Theory, 29, 5 (2001), pp. 670-90.

113 Ibid., pp. 681, 689.

114 D. Della Porta and M. Diani, Social Movements: An Introduction (Oxford, Blackwell, 1999), p. 238.

115 Goodwin and Jasper, The Social Movements Reader, p. 347; McAdam et al., Comparative Perspectives on Social Movements, p. 14.

116 Estrella and Iszatt, cited in Gaventa, 'Triumph, Deficit or Contestation? Deepening the "Deepening Democracy" Debate', p. 264.

117 J. Migdal, 'The State in Society: an Approach to Struggles for Domination', in J. Migdal, A. Kohli and V. Shue (eds), State Power and Social Forces (Cambridge, Cambridge University Press, 1994), p. 8. 
influence that do not fit in its strategic agenda. Rather, Sikhula Sonke shows that individuals can be influenced (the Provincial Minster of Agriculture), institutions utilised (the CCMA) and local state bodies made to operate more effectively (the Somerset West Labour Centre). Understanding how state structures work and how these can be influenced and lobbied is an effective way of generating government responsiveness and strengthening democracy.

Many social movement activists would disagree with this perspective, arguing that the state has demonstrated only hostility towards post-apartheid social movements. ${ }^{118}$ According to one activist, the state's response to new social movements has been 'at best to marginalise them and at worst to criminalise them'. ${ }^{119}$ Many of these claims are valid and cause for concern. There are examples of where attempts have been made to censor social movement activities, including prohibiting marches and gatherings. ${ }^{120}$ However, as Greenstein explains, the state is multifaceted. While one arm can be involved in the violation of human rights (the police), the other can be monitoring their practice and protecting them from offenders (HRC and the Constitutional Court). Thus, one should not 'pit a unitary state against a unified civil society but rather allow for the interpenetration of sectors and crossing of boundaries between them' ${ }^{121}$ The state is a terrain where power is wielded, and discourse and practice shaped. ${ }^{122}$ Where movements do not form relationships with the different facets of the state they lose the opportunity to be part of the 'power that is wielded' and contribute to the formation of 'discourse' and its implementation in 'practice'. Social movements can thus learn from Sikhula Sonke and so strengthen democracy where they adopt a multifaceted and flexible approach to influencing the different elements of the state.

In conclusion, it can be argued social movement activity, as demonstrated by Sikhula Sonke, not only meets its members' immediate needs, but also, although not a direct aim, strengthens democracy. Certainly Sikhula Sonke is successful in meeting its own aims: it is creating a democratic organisation while being cognisant of the challenges in setting up representative structures run by previously disempowered farm workers; it embraces and effectively uses its hybrid social movement trade union status to tackle wide ranging farm worker concerns; it is consistently, and with some effect, addressing social inequality on Western Cape farms; and it successfully challenges unfair labour practices on a case by case basis, as well as at a broader governmental level. Sikhula Sonke's strategies, however, also point to ways in which social movements strengthen democracy, making it more responsive to the needs of the poor. Where Sikhula Sonke empowers citizens, strengthens political institutions, uses radical and moderate flanks and embraces the multi-dimensional nature of the state, it implicitly strengthens democracy. The movement's work in this regard is important. After all, it is democracy that South Africans' fought so hard for, and indeed

118 D. McKinley and A. Veriava, Arresting Dissent: State Repression and Post-Apartheid Social Movements (Braamfontein, Centre for the Study of Violence and Reconciliation, 2005); A. Desai, We are the Poors: Community Struggles in Post-Apartheid South Africa (New York, Monthly Review Press, 2002).

119 T. Madlingozi, 'Post-Apartheid Social Movements and the Quest for the Elusive "New" South Africa', Journal of Law and Society, 34, 1 (2007), pp. 76-97, p. 80.

120 P. Naidoo, Establishing a Historical Record of Violations of the Regulation of Gatherings Act and the Right to Freedom of Assembly amongst Social Movements in Johannesburg (Johannesburg, Freedom of Expression Institute, undated); R. Ballard, 'Social Movements in Post-Apartheid South Africa: An Introduction', in P. Jones and K. Stokke (eds), Democratising Development: The Politics of Socio-Economic Rights in South Africa (Leiden, Martinus Nijhoff Publishers, 2005), p. 89; J. Duncan, 'The State of State Repression in South Africa', Debate: Voices from the South African Left, 11 (March 2005).

121 R. Greenstein, 'Civil Society, Social Movements and Power in South Africa' (unpublished paper, Johannesburg, 2003), p. 6.

122 S. Greenberg and N. Ndlovu, 'Civil Society Relationships', Development Update, 5, 2 (2004), pp. 23-48, p. 47. 
it is democracy that holds the promise of improving the everyday lives of the country's poor and marginalised citizens.

\section{FIONA WHITE}

Centre for the Study of Democracy, Rhodes University/University of Johannesburg, South Africa.E-mail: fiona.a.white@gmail.com 
Copyright of Journal of Southern African Studies is the property of Routledge and its content may not be copied or emailed to multiple sites or posted to a listserv without the copyright holder's express written permission. However, users may print, download, or email articles for individual use. 